\title{
Increased production of a proliferation-inducing ligand (APRIL) by the peripheral blood mononuclear cells predicts worse prognosis in patients with systemic sclerosis
}

\author{
Wzmożona synteza liganda indukującego proliferację (APRIL) przez komórki \\ jednojądrowe krwi obwodowej wiąże się z gorszym rokowaniem u chorych \\ na twardzinę układowa
}

\author{
Marek Bielecki ${ }^{1}$, Krzysztof Kowal ${ }^{2}$, Pawel Bernatowicz³ ${ }^{3}$ Lech Chyczewski ${ }^{3}$, Otylia Kowal-Bielecka ${ }^{4}$ \\ 1Department of Orthopedics and Traumatology, Medical University of Bialystok, Bialystok, Poland \\ 2Department of Allergology and Internal Medicine, Medical University of Bialystok, Bialystok, Poland \\ ${ }^{3}$ Department of Medical Pathomorphology, Medical University of Bialystok, Bialystok, Poland \\ ${ }^{4}$ Department of Rheumatology and Internal Medicine, Medical University of Bialystok, Bialystok, Poland \\ ${ }^{1}$ Klinika Ortopedii i Traumatologii, Uniwersytet Medyczny w Białymstoku \\ ${ }^{2}$ Klinika Alergologii i Chorób Wewnętrznych, Uniwersytet Medyczny w Białymstoku \\ 3Zakład Patomorfologii Lekarskiej, Uniwersytet Medyczny w Białymstoku \\ ${ }^{4}$ Klinika Reumatologii i Chorób Wewnętrznych, Uniwersytet Medyczny w Białymstoku
}

Key words: systemic sclerosis, scleroderma, APRIL, pathogenesis, biomarker.

Słowa kluczowe: twardzina układowa, skleroderma, APRIL, patogeneza, biomarker.

\section{Sum mary}

Objectives: A proliferation-inducing ligand (APRIL) plays a crucial role in survival of the peripheral B cells, and may contribute to the pathogenesis of systemic sclerosis (SSc) through upregulation of autoantibody production and maintenance of the autoimmune phenomenon. It has recently been shown that peripheral blood mononuclear cells (PBMC) from patients with SSc release significantly greater amounts of APRIL as compared with healthy controls (HC).

Aim of the study: To better understand the role of APRIL in the development of SSc we aimed to investigate the relationships between production of APRIL by PBMC and clinical outcome in patients with SSc. Material and methods: Concentration of APRIL was measured in PBMC supernatants from 22 SSc patients and 17 healthy subjects using commercially available ELISA kits. SSc patients were subsequently followed for at least three years or until death, whichever happened earlier. Disease progression was defined as death due to SSc-related organ complication, development of a new or progression of pre-existing SSc-related organ involvement.

\section{Streszczenie}

Wprowadzenie: Ligand indukujący proliferację (a proliferation inducing ligand - APRIL) odgrywa dominującą rolę w przeżyciu komórek B i może brać udział w patogenezie twardziny układowej (TU) poprzez stymulację syntezy autoprzeciwciat i procesów autoimmunologicznych. Ostatnio wykazano, że komórki jednojądrowe krwi obwodowej (KJKO) pacjentów z TU uwalniają istotnie większe ilości APRIL w porównaniu z komórkami osób zdrowych.

Cel pracy: W celu lepszego zrozumienia znaczenia APRIL w rozwoju TU zbadano zależność pomiędzy uwalnianiem APRIL przez KJKO a przebiegiem choroby u pacjentów z TU.

Materiał i metody: Stężenie APRIL oznaczano za pomocą metody ELISA w nadsączu hodowli KJKO u 22 chorych z TU i 17 osób zdrowych. Pacjenci z TU byli następnie obserwowani przez przynajmniej 3 lata bądź do śmierci (jeśli nastąpiła wcześniej). Progresję choroby definiowano jako: zgon spowodowany powikłaniami narządowymi TU, wystąpienie nowych lub istotne pogorszenie już istniejących powikłań narządowych TU.

Address for correspondence:

Otylia Kowal-Bielecka, MD, Department of Rheumatology and Internal Medicine, Medical University of Bialystok, ul. M. Sklodowskiej-Curie 24 A, 15-276 Bialystok, Poland, phone +48 8574684 82, fax +48 8574686 06, e-mail: otylia@umb.edu.pl Submitted: 28.08 .2012 
Results: Concentration of APRIL was significantly greater in supernatants of PBMC from SSC $\left(1097 \pm 240 \mathrm{pg} / \mathrm{ml} / \mathrm{10}^{5}\right)$ as compared with HC (851 $\left.\pm 171 \mathrm{pg} / \mathrm{ml} / 10^{5}, p<0.05\right)$. In SSc patients APRIL levels correlated with the severity of skin and lung involvement. PBMC from 7 patients who experienced progression of the disease released significantly greater amounts of APRIL ( $1326 \pm 105 \mathrm{pg} / \mathrm{ml} / 10^{5}$ cells) as compared with those SSc patients with stable disease $\left(991 \pm 208 \mathrm{pg} / \mathrm{ml} / 10^{5}\right.$ cells, $\left.p<0.05\right)$ and $\mathrm{HC}$. In regression analysis concentration of APRIL was independently associated with disease outcome ( $\beta$ coeff $=-0.94, p=0.0009$ ). Conclusions: We show for the first time that increased release of APRIL by PBMC is associated with worse disease outcome in SSc. Further studies are needed to investigate whether targeting APRIL might rep resent a new therapeutic possibility for treatment of SSc patients.

\section{Introduction}

Systemic sclerosis (SSc, scleroderma) is a chronic connective tissue disease characterized by profound fibrosis of the skin and internal organs [1]. Although fibrosis is considered the most characteristic feature of scleroderma, it is believed to represent already the final, irreversible stage of the disease [2]. Clinical observations and experimental data indicate that activation of immune cells and immunologically driven inflammation play an important role in the development of the disease [1-4]. The mechanisms through which the immune system might trigger fibrosis are complex and yet not fully understood. Recently, B-cells have gained great attention as key players in SSC pathogenesis and a possible target of therapy in scleroderma $[5,6]$. Indeed, it has long been recognized that antinuclear antibodies (ANA) are present in all SSc patients, often before other manifestations become apparent, and diseasespecific autoantibodies are associated with particular clinical presentations and prognosis [1, 7]. B-cells are found in mononuclear cell infiltrates which are present in the skin, lungs and other organs in early disease $[5,6]$. Recently, it has been shown that expression of cytokines regulating B cell survival and function is increased in SSC $[5,6]$.

A proliferation-inducing ligand (APRIL) is a member of the tumor necrosis factor (TNF) superfamily of molecules; it stimulates B-cell and plasma cell survival and regulates immunoglobulin class-switching [8]. APRIL has, therefore, been implicated in the pathogenesis of B-cell derived malignancies as well as autoimmune diseases [9-11]. However, only a few studies investigating APRIL in patients with SSc have been published so far [12-14]. Two studies showed that concentration of APRIL is increased in the sera of patients with SSc but revealed different associations with clinical features of the disease [12, 13]. We have recently investigated in vitro release of APRIL by the peripheral blood mononuclear cells (PBMC), which are considered an important source of APRIL in humans and are major constituents of inflammatory infiltrates found in the skin and internal organs in early SSc. We have shown that in vitro release of APRIL by PBMC from SSc patients is increased
Wyniki: Stężenie APRIL było znacząco większe w nadsączu KJKO chorych na TU $(1097 \pm 240$ pg/ml/105) w porównaniu z osobami zdrowymi $\left(851 \pm 171 \mathrm{pg} / \mathrm{ml} / 10^{5}, p<0,05\right)$. U chorych na TU poziom APRIL korelował z zajęciem skóry i płuc. U 7 osób z progresją choroby stwierdzono znacząco większe stężenie APRIL (1326 \pm 105 pg/ml/105) w porównaniu ze stężeniem w grupie chorych ze stabilną choroba $(991 \pm 208$ pg/ml/105 $, p<0,05)$ i u osób zdrowych. W analizie regresji wieloczynnikowej stężenie APRIL było niezależnie związane z wynikiem końcowym choroby $(\beta=-0,94, p=0,0009)$.

Wnioski: Po raz pierwszy wykazano, że wzmożone uwalnianie APRIL przez KJKO jest związane z gorszym rokowaniem u chorych na TU. Dalsze badania powinny wykazać, czy APRIL może stanowić nowy cel terapeutyczny w TU.

\section{Wstęp}

Twardzina układowa (TU, skleroderma) jest układową chorobą tkanki łącznej charakteryzującą się rozległym zwłóknieniem skóry i narządów wewnętrznych [1]. Chociaż włóknienie jest najbardziej typową cechą TU, uważa się, że stanowi ono końcowy, nieodwracalny okres choroby [2]. Obserwacje kliniczne oraz wyniki badań eksperymentalnych wskazują, że aktywacja komórek układu immunologicznego i zapalenie wywołane procesami immunologicznymi odgrywają istotną rolę w rozwoju TU [1-4]. Mechanizmy immunologiczne odpowiedzialne za rozwój włóknienia są skomplikowane i nie do końca poznane. Ostatnio zwrócono uwagę na rolę komórek B w patogenezie TU oraz ich potencjalną rolę w leczeniu chorych na TU $[5,6]$. Od dawna wiadomo, że swoiste przeciwciała przeciwjądrowe (antinuclear antibodies - ANA) są obecne u chorych na TU zwykle jeszcze przed pojawieniem się objawów klinicznych, a ich obecność wiąże się z określonym przebiegiem klinicznym choroby [1, 7]. Komórki B występują w naciekach zapalnych stwierdzanych w skórze, płucach i innych narządach we wczesnej fazie choroby [5, 6]. Ostatnio u chorych na TU zaobserwowano wzrost ekspresji cytokin, które wpływają na przeżycie i funkcję komórek B $[5,6]$.

Ligand indukujący proliferację (a proliferation inducing ligand - APRIL) należy do nadrodziny czynnika martwicy nowotworów (tumornecrosis factor - TNF) i wpływa na przeżycie komórek B oraz komórek plazmatycznych, a także bierze udział w procesach regulacji zmiany klasy immunoglobulin [8]. W związku z powyższym uważa się, że APRIL odgrywa rolę $w$ patogenezie nowotworów wywodzących się z komórek B, a także chorób autoimmunologicznych [9-11]. Dotychczas opublikowano niewiele prac dotyczących roli APRIL u chorych na TU [12-14]. Dwa doniesienia wskazują, że stężenie APRIL zwiększa się w surowicy chorych na TU, różnią się one jednak pod względem stwierdzonych związków pomiędzy stężeniem APRIL w surowicy a klinicznym obrazem choroby $[12,13]$.

Autorzy artykułu badali in vitro uwalnianie APRIL przez komórki jednojądrowe krwi obwodowej (KJKO), 
as compared with healthy subjects and that increased release of APRIL by PBMC is associated with more severe skin and lung disease in SSc [14].

This study was undertaken to further understand the role of APRIL in the pathogenesis of SSc through investigation of relationships between in vitro release of APRIL by PBMC and clinical course in patients with SSc. For this purpose we correlated the baseline in vitro release of APRIL in PBMC and the results of three-year prospective observation in 22 SSc patients.

\section{Material and methods}

\section{Patients}

Twenty-two patients (20 female and 2 male) fulfilling the ACR (American College of Rheumatology) classification criteria for SSc and/or the definition of early SSc as proposed by LeRoy et al. were included $[15,16]$. To avoid modification of the activity of leukocytes by immunosuppressive drugs only patients who had not taken any immunosuppressive therapies or in whom immunosuppressive therapies had been stopped at least 6 months before blood collection were considered eligible. SSc patients were classified as having diffuse cutaneous SSc (dSSc) or limited cutaneous SSc (ISSc) based on criteria of LeRoy et al. [17]. For every patient, duration of Raynaud's phenomenon and duration of the disease, calculated from the time of the first non-Raynaud's symptom attributable to SSc, were recorded. Skin involvement was assessed using the modified Rodnan skin score (mRSS) as described elsewhere [18]. The presence of scleroderma interstitial lung disease (SLD) was defined based on the presence of features of interstitial fibrosis and/or "ground glass" pacifications in high resolution computed tomography (HRCT) of the lungs. Pulmonary function tests were used to evaluate the severity of lung involvement including measurements of the forced vital capacity (FVC) and diffusing capacity of the lungs for carbon monoxide (DLCO). Pulmonary hypertension was defined as pulmonary artery systolic pressure (PASP) higher than $45 \mathrm{mmHg}$, as measured by echo-Doppler. Laboratory parameters included assessment of the presence of antinuclear antibodies (ANA), anti centromere antibodies (ACA), anti-topoisomerase I antibodies (anti-topo I, anti-Scl70) and erythrocyte sedimentation rate (ESR). Capillaroscopy was used to identify SSc-related microangiopathy and specific patterns of capillary injury. Capillaroscopic patterns were classified according to the classification by Carpentier and Maricq as a "slow" pattern characterized by preserved architecture of the vascular layout and the presence of megacapillaries, or as an "active" pattern characterized by irregular drop-out of capillaries resulting in disrupted architecture of the vascular layout, the presence of megacapillaries and/or bushy capillaries [19]. które są ważnym źródłem APRIL u ludzi oraz głównym składnikiem nacieków zapalnych spotykanych w skórze i narządach wewnętrznych we wczesnym okresie TU [14]. Wykazano, że KJKO chorych na TU w warunkach in vitro uwalniają istotnie większe ilości czynnika APRIL (w porównaniu z osobami zdrowymi) oraz że wzmożone wydzielanie APRIL przez KJKO jest związane z bardziej nasilonym zajęciem skóry i płuc u chorych na TU [14].

Obecne badania miaty na celu lepsze poznanie roli APRIL w patogenezie TU poprzez ocenę związku pomiędzy wydzielaniem APRIL in vitro przez KJKO a przebiegiem klinicznym TU. W tym celu zbadano korelację pomiędzy uwalnianiem APRIL przez KJKO in vitro z wynikami 3-letnich prospektywnych obserwacji u 22 chorych na TU.

\section{Materiat i metody \\ Pacjenci}

W badaniu wzięło udział 22 pacjentów (20 kobiet i 2 mężczyzn), którzy spełnili kryteria klasyfikacyjne ACR i/lub definicję wczesnej postaci TU, jaką zaproponowali LeRoy i wsp. [15, 16]. Do badania kwalifikowano chorych, którzy nie przyjmowali żadnych leków immunosupresyjnych lub u których zaprzestano podawania takich leków przynajmniej 6 miesięcy przed pobraniem próbek krwi. W ten sposób unikano modyfikacji aktywności leukocytów przez leki immunosupresyjne. Postać choroby określano jako uogólnioną TU (diffuse SSc - dSSc) bądź ograniczoną TU (limited SSc - ISSc), zgodnie z kryteriami LeRoy i wsp. [17]. U każdego chorego określano czas trwania objawu Raynauda, a także czas trwania choroby określany od momentu pojawienia się pierwszego objawu choroby, innego niż objaw Raynauda. Zakres zmian skórnych oceniano na podstawie zmodyfikowanej skali Rodnana (modified Rodnan skin score - mRSS) [18]. Rozpoznanie śródmiąższowej choroby płuc (ŚChP) ustalano na podstawie obecności cech włóknienia śródmiąższowego i/lub obrazu „mlecznej szyby" w tomografii komputerowej płuc wysokiej rozdzielczości (TKWR). Stopień zajęcia płuc oceniano na podstawie testów czynnościowych płuc, obejmujących pomiar natężonej pojemności życiowej (forced vital capacity-FVC) oraz pojemności dyfuzyjnej płuc dla tlenku węgla (diffusing capacity of the lungs for carbon monoxide DLCO). Nadciśnienie płucne definiowano jako skurczowe ciśnienie w tętnicy płucnej (pulmonary artery systolic pressure - PASP) przewyższające $45 \mathrm{~mm} \mathrm{Hg}$, w badaniu echo-Doppler. Badania laboratoryjne obejmowały ocenę obecności ANA, przeciwciał antycentromerowych (anticentromere antibodies - ACA), przeciwciat przeciwko topoizomerazie I (anti-topoisomerase I antibodies - antitopo I, anti-Scl70) oraz prędkość opadania krwinek (OB). Obecność mikroangiopatii oceniano na podstawie wyników badania kapilaroskopowego. Zmiany w mikrokrąże- 
Disease progression was defined as death due to an SSc-related organ complication, development of a new one or worsening of pre-existing SSc-related organ involvement. As in other studies, worsening of internal organ involvement was defined as an increase in mRSS of $\geq 25 \%$, a decrease in FVC of $\geq 10 \%$ in patients with SLD, an increase in dyspnea by at least one WHO/NYHA class in patients with $\mathrm{PH}$ or heart failure, or the need for chronic dialysis in patients with scleroderma renal crisis or parenteral nutrition in patients with gastrointestinal involvement $[18,20]$. Eleven of the patients included in this study participated in our study reported previously [14].

The control group consisted of 17 healthy subjects (14 female and 3 male).

The study protocol was approved by the local bioethics committee and appropriate informed consent was obtained from all patients.

\section{Cell cultures and measurements of APRIL in PBMC supernatants}

PBMC were isolated from the whole blood using density gradient centrifugation as described previously [14]. The isolated PBMC were resuspended in RPMI medium supplemented with $5 \%$ fetal calf serum at a density $10^{5}$ cells $/ \mathrm{ml}$ and cultured at $37^{\circ} \mathrm{C}$ under $5 \% \mathrm{CO}_{2}$ for 24 hours. Subsequently the cells were centrifuged and supernatants were collected and frozen at $-80^{\circ} \mathrm{C}$ until measurements. Evaluation of APRIL concentration in the supernatants was performed using commercially available ELISA kits (Bender MedSystems GmbH).

\section{Statistical analysis}

For the assessment of between-group comparisons the ANOVA test and Mann-Whitney $U$ test were used, as appropriate. Correlations were evaluated using the Spearman correlation test. Relative contribution of independent variables to the outcome of SSc was investigated by means of regression analysis. The differences were considered significant at $p$ values lower than 0.05 .

All results are expressed as mean \pm standard deviation (SD) unless stated otherwise.

\section{Results}

\section{Clinical characteristic of SSc patients}

Out of 22 SSc patients included in the study, eight (36\%) had diffuse form of the disease while the remaining 14 (64\%) had limited SSc. HRCT of the lungs revealed features of SLD in 10 (46\%) of the SSc patients and pulmonary hypertension by echocardiography was found in 3 (14\%) of them. All patients included in the study had Raynaud's phenomenon while digital ulcers and/or pitting scars were niu klasyfikowano wg Carpentiera i Maricq jako zmiany „łagodne” (slow pattern) charakteryzujące się zachowaniem architektury naczyń i obecnością megakapilar bądź zmiany aktywne (active pattern) cechujące się awaskularyzacją i zaburzeniem architektury naczyń i/lub obecnością kapilar „drzewkowatych” [19].

Progresję choroby definiowano jako zgon spowodowany powikłaniami narządowymi TU, istotne pogorszenie już istniejących bądź pojawienie się nowych powikłań narządowych TU. Podobnie jak we wcześniejszych badaniach, istotne pogorszenie powikłań narządowych TU definiowano jako: wzrost mRSS o ponad 25\%, zmniejszenie FVC o ponad 10\% (u chorych na ŚChP), narastanie duszności przynajmniej o jedną klasę w klasyfikacji WHO/NYHA u chorych z nadciśnieniem płucnym bądź niewydolnością serca, wskazanie do przewlekłej dializoterapii u osób z przełomem nerkowym, konieczność odżywiania parenteralnego u pacjentów z zajęciem przewodu pokarmowego [18, 20]. Jedenastu chorych zakwalifikowanych do niniejszego badania uczestniczyło w badaniu wcześniejszym [14].

Grupa kontrolna składała się z 17 zdrowych osób (14 kobiet i 3 mężczyzn).

Protokół badania uzyskał akceptację lokalnej komisji bioetycznej, a wszyscy pacjenci wyrazili pisemną zgodę na udział w badaniu.

\section{Hodowle komórek jednojądrowych krwi obwodowej i ocena stężenia APRIL w supernatantach komórek jednojądrowych krwi obwodowej}

Podobnie jak we wcześniejszym badaniu, KJKO były izolowane z pełnej krwi metodą wirowania w gradiencie stężeń [14]. Wyizolowane KJKO były zawieszane w medium RPMI wzbogaconym 5-procentową płodową surowicą cielęcą, $10^{5} \mathrm{komórek} / \mathrm{ml}$, i inkubowane przez 24 godziny w temperaturze $37^{\circ} \mathrm{C}$ i atmosferze zawierającej $5 \% \mathrm{CO}_{2}$. Następnie komórki były odwirowywane, a supernatant był zbierany i zamrażany $w$ temperaturze $-80^{\circ} \mathrm{C}$ do czasu badań. Stężenie APRIL w supernatancie hodowli komórkowych było określane przy użyciu komercyjnie dostępnego zestawu ELISA (Bender MedSystems GmbH).

\section{Analiza statystyczna}

W ocenie statystyczno-porównawczej stosowano testy ANOVA oraz test U Manna-Whitneya. Korelacje badano na podstawie testu Spearmana. Analizę regresji wieloczynnikowej wykorzystano w celu oceny znaczenia poszczególnych czynników w ocenie progresji choroby. Różnice były określane jako znamienne statystycznie przy wartości $p<0,05$. Wszystkie wyniki są przedstawiane jako średnie oraz odchylenie standardowe. 
present in 12 (55\%) of them. Characteristic microangiopathy was found in all SSc patients: the "active" pattern was present in 10 patients while the remaining 12 had the "slow" pattern. ANA, ACA and anti-topo I antibodies were found in $100 \%, 27 \%$ and $55 \%$, respectively. None of our patients had scleroderma crisis. Detailed clinical characteristics of the patients are given in Table I.

\section{APRIL in SSc patients and healthy controls}

The mean concentration of APRIL in PBMC culture supernatants was significantly greater in SSc patients (1097 $\left.\pm 240 \mathrm{pg} / \mathrm{ml} / 10^{5}\right)$ as compared with that of healthy controls (851 \pm 171 pg/ml/105, $p<0.05$ vs. SSc patients) (Fig. 1).

In SSc patients release of APRIL by PBMC showed significant associations with the severity of the disease. Accordingly, concentration of APRIL in PBMC cultures was greater in patients with dSSC as compared with ISSc, greater in patients with SLD than in those without SLD, greater in patients with more severe capillary damage, as indicated by presence of the "active" capillaroscopic pattern as compared with those with less capillary damage, as indicated by the "slow" capillary pattern ( $p<0.05$ for all comparisons). Concentration of APRIL significantly correlated with $\mathrm{mRSS}(R=0.77, p=0.00008)$ and $\mathrm{ESR}(R=0.55$, $p=0.01)$, and showed an inverse correlation with FVC predicted $(R=-0.48, p=0.03)$. In addition, production of APRIL was greater in patients with anti-topo I autoantibodies as compared with those without anti-topo I $(p<0.05)$. Accordingly, release of APRIL was significantly greater in patients without ACA as compared with ACA-positive patients $(p<0.05)$. There was no correlation between APRIL levels and any other parameter of the disease, including disease duration, duration of Raynaud's phenomenon, or predicted DLCO values.

\section{Relationships between release of APRIL by PBMC and disease progression in patients with SSc}

During follow-up, 7 out of 22 (32\%) SSc patients died or experienced worsening of SSc-related organ involvement, as defined in the methods section. In the remaining 15 SSc patients disease remained stable over the three-year follow-up. The detailed comparison of SSc patients with and without progression of the disease is presented in Table I. The mean ( \pm SD) time of Raynaud's phenomenon was significantly shorter in SSc patients with subsequent progression of the disease or death ( $3.9 \pm 3.7$ years) as compared with those who had a stable course of the disease $(8.1 \pm 5.6$ years, $p<0.05)$. Scleroderma patients who experienced death or clinical worsening had significantly greater skin involvement (mean \pm SD of mRSS: $21.9 \pm 12.0$ ) as compared with patients with stable disease $(8.6 \pm 7.3, p<0.05)$. Frequency

\section{Wyniki \\ Kliniczna charakterystyka pacjentów z twardziną układową}

Spośród 22 chorych z TU biorących udział w badaniu 8 (36\%) miało postać uogólnioną choroby (dSSc), natomiast pozostałych 14 (64\%) - postać ograniczoną (ISSc). W TKWR płuc cechy ŚChP stwierdzono u 10 chorych (46\%), a nadciśnienie płucne w badaniu echokardiograficznym zdiagnozowano u 3 pacjentów z wyżej wymienionej grupy (14\%). Wszyscy chorzy zakwalifikowani do badania mieli objaw Raynauda, natomiast owrzodzenia troficzne i/lub blizny naparstkowate występowały u 12 chorych (55\%). Charakterystyczną mikroangiopatię stwierdzono u wszystkich pacjentów z TU: zmiany o charakterze aktywnym (active pattern) były obecne u 10 chorych, natomiast zmiany łagodne (slow pattern) u 12 chorych. Przeciwciała przeciwjądrowe, ACA i przeciwciała anty-topo I stwierdzano odpowiednio u 100\%, $27 \%$ oraz 55\% chorych. W momencie kwalifikacji chorych do badania u żadnego z badanych nie odnotowano przełomu nerkowego. Dokładną kliniczną charakterystykę chorych przedstawiono w tabeli I.

\section{Stężenia APRIL u chorych na twardzinę układową i w grupie kontrolnej}

Średnie stężenie APRIL w hodowlach KJKO było znamiennie statystycznie wyższe u chorych na TU (1097 \pm 240 pg/ml/105) niż u osób zdrowych (851 ×171 pg/ml/105, $p<0,05)$ (ryc. 1).

U chorych na TU uwalnianie APRIL przez KJKO wykazywało istotny związek ze stopniem ciężkości choroby. Tak więc stężenie APRIL w hodowlach KJKO było większe u chorych z uogólnioną formą choroby (dSSc) w porównaniu ze stężeniem u chorych z ograniczoną postacią choroby (ISSc). Większe stężenie APRIL stwierdzano u osób ze ŚChP oraz u pacjentów z bardziej zaawansowanymi zmianami w mikrokrążeniu (active pattern) w porównaniu z odpowiednio: chorymi bez ŚChP oraz ze zmianami typu łagodnego w mikrokrążeniu (slow pattern). Stężenie APRIL korelowało ze zmianami skórnymi wg zmodyfikowanej skali Rodnana $(R=0,77, p=0,00008)$ i z prędkością opadania krwinek czerwonych $(R=0,55$, $p=0,01)$. Stwierdzono także odwrotną korelację stężenia APRIL w stosunku do wartości FVC $(R=-0,48, p=0,03)$. Ponadto stężenie APRIL było większe $u$ chorych z przeciwciałami anty-topo I w porównaniu z chorymi bez tych przeciwciał. Uwalnianie APRIL było natomiast znamiennie wyższe u chorych bez przeciwciał ACA w porównaniu z chorymi z obecnością ACA. Nie stwierdzono korelacji pomiędzy stężeniem APRIL a innymi parametrami choroby, takimi jak: czas trwania objawu Raynauda, czas trwania choroby czy wartości DLCO. 
Table I. Baseline clinical characteristics of the total population of patients with systemic sclerosis, patients with clinical progression of the disease, those with stable disease course and the control group. All data are presented as mean \pm SD unless stated otherwise

Tabela I. Wyjściowa charakterystyka kliniczna wszystkich chorych na twardzinę układowa (TU), chorych na TU, którzy doświadczyli progresji choroby, chorych na TU ze stabilnym przebiegiem choroby oraz osób z grupy kontrolnej. Dane przedstawione sa w postaci średniej $\pm S D$, o ile nie zaznaczono inaczej

\begin{tabular}{|c|c|c|c|c|}
\hline Parameter/Parametr & $\begin{array}{l}\text { SSc patients/ } \\
\text { Pacjenci z TU } \\
(n=22)\end{array}$ & $\begin{array}{l}\text { SSc patients } \\
\text { with disease } \\
\text { progression/ } \\
\text { Pacjenci z TU } \\
\text { i progresja choroby } \\
(n=7)\end{array}$ & $\begin{array}{l}\text { SSc patients } \\
\text { with stable disease/ } \\
\text { Pacjenci z TU } \\
\text { i stabilnym } \\
\text { przebiegiem choroby } \\
\quad(n=15)\end{array}$ & $\begin{array}{c}\text { Control } \\
\text { group/ } \\
\text { Grupa } \\
\text { kontrolna } \\
(n=17)\end{array}$ \\
\hline female/male ratio/kobiety/mężczyźni & $20 / 2$ & $5 / 2$ & $15 / 0$ & $14 / 3$ \\
\hline age (mean, range)/wiek (średnia, zakres) & $49.3 \pm 12.0$ & $51.0 \pm 13.5$ & $48.5 \pm 12.3$ & $43.7 \pm 15.4$ \\
\hline $\begin{array}{l}\text { disease duration in years/czas trwania } \\
\text { choroby (lata) }\end{array}$ & $2.4 \pm 2.8$ & $0.9 \pm 0.8$ & $3.0 \pm 3.2$ & \\
\hline $\begin{array}{l}\text { duration of Raynaud's phenomenon in years/ } \\
\text { czas trwania objawu Raynauda }\end{array}$ & $6.8 \pm 5.4$ & $3.9 \pm 3.7^{\star}$ & $8.1 \pm 5.6$ & \\
\hline dSSc/ISSc & $8 / 14$ & $5 / 2$ & $3 / 12$ & \\
\hline mRSS & $13.3 \pm 11.6$ & $21.9 \pm 12.0^{*}$ & $8.6 \pm 7.3$ & \\
\hline ANA positive/obecne ANA (\%) & $23(100)$ & $7(100)$ & $15(100)$ & \\
\hline $\begin{array}{l}\text { Anti-Scl70 positive/obecne przeciwciata } \\
\text { anty-Scl70 (\%) }\end{array}$ & $12(55)$ & $6(86)$ & $6(40)$ & \\
\hline ACA positive/obecne ACA (\%) & $6(27)$ & 0 & $6(40)$ & \\
\hline Raynaud's phenomenon/objaw Raynauda (\%) & $22(100)$ & $7(100)$ & $15(100)$ & \\
\hline SLD by HRCT/X ray/ŚChP W TKWR/RTG (\%) & $10(46)$ & $5(71)$ & $5(30)$ & \\
\hline pulmonary hypertension/nadciśnienie płucne (\%) & $3(14)$ & $2(29)$ & $1(7)$ & \\
\hline FVC (\% predicted)/FVC (\% wartości należnej) & $103.9 \pm 17.9$ & $91.8 \pm 27.6$ & $108.1 \pm 19.5$ & \\
\hline DLCO (\% predicted)/DLCO (\% wartości należnej) & $84.6 \pm 21.2$ & $73.2 \pm 25.6$ & $88.2 \pm 25.6$ & \\
\hline $\begin{array}{l}\text { digital ulcers and/or pitting scars/ } \\
\text { owrzodzenia palców i/lub blizny naparstkowate (\%) }\end{array}$ & $12(55)$ & $5(71)$ & 7 (32) & \\
\hline $\begin{array}{l}\text { capillaroscopic pattern (“active”/“slow”)/typ zmian } \\
\text { w kapilaroskopii (,active”/,slow”) }\end{array}$ & $10 / 12$ & $5 / 2$ & $5 / 10$ & \\
\hline $\mathrm{ESR} / O B(\mathrm{~mm} / \mathrm{h})$ & $21.3 \pm 17.2$ & $34.9 \pm 31.1$ & $20.7 \pm 11.5$ & \\
\hline $\begin{array}{l}\text { number of deaths during follow-up/ } \\
\text { liczba zgonów (\%) }\end{array}$ & $2(9)$ & $2(29)$ & 0 & \\
\hline
\end{tabular}

${ }^{*} p<0.05$ vs. SSc patients with stable disease $/{ }^{*} p<0,05$ w porównaniu z chorymi na TU ze stabilnym przebiegiem choroby, ACA - anti-centromere antibodies/przeciwciata antycentromerowe, ANA - antinuclear antibodies/przeciwciata antyjądrowe, DLCO - diffusing capacity of the lungs for carbon monoxide/ pojemność dyfuzyjna płuc dla tlenku węgla, dSSc - diffuse systemic sclerosis/uogólniona postać TU, ESR - erythrocyte sedimentation rate/odczyn Biernackiego, FVC - forced vital capacity/natężona pojemność życiowa, ISSC - limited systemic sclerosis/ograniczona postać TU, mRSS - modified Rodnan skin scorel zmodyfikowany wskaźnik zmian skórnych wg Rodnana, SLD - scleroderma lung disease/śródmiąższowa choroba płuc, HRCT - high resolution computed tomography/tomografia komputerowa wysokiej rozdzielczości 


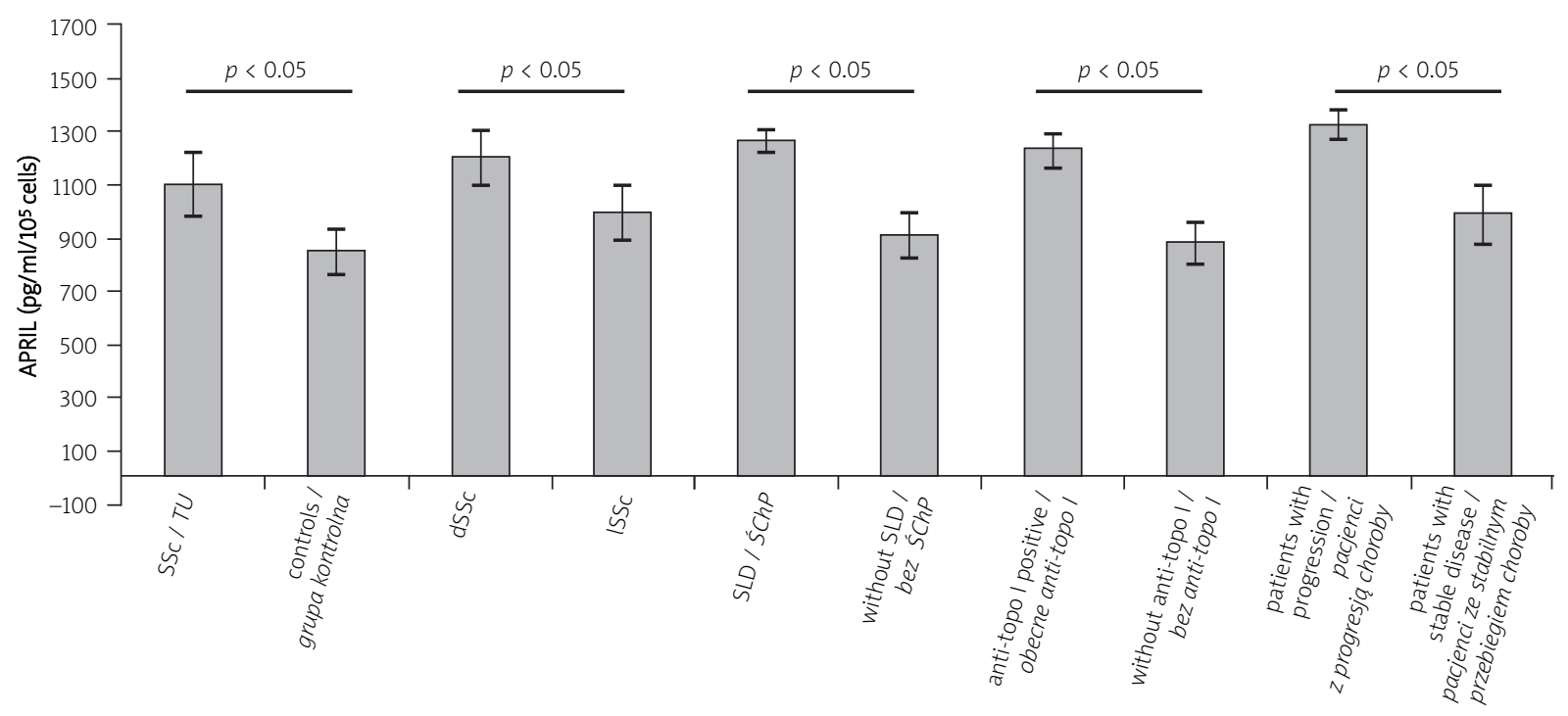

dSSC - diffuse systemic sclerosis / uogólniona postać twardziny układowej, ISSC - limited systemic sclerosis / ograniczona postać twardziny układowej, SSc - systemic sclerosis / TU - twardzina układowa, SLD - scleroderma interstitial lung disease / ŚChP - śródmiąższowa choroba płuc

Fig. 1. Concentration of APRIL in supernatants from peripheral blood mononuclear cells from patients with systemic sclerosis, different subgroups of patients with systemic sclerosis and control subjects.

Ryc. 1. Stężenie APRIL w supernatantach z komórek jednojądrowych krwi obwodowej u chorych na twardzinę układową, z różnymi postaciami twardziny układowej i w grupie kontrolnej.

of diffuse form of disease and anti-Scl70 antibodies tended to be higher in patients with worse prognosis as compared with those with stable disease although the differences were not significant $(p=0.05$ and $p=0.07$, respectively) (Table I).

Anti centromere antibodies were present in $40 \%$ of patients with stable disease and none of those with clinical progression. No other significant differences could be found between patients with worse clinical outcome and those with stable disease including age, duration of SSc defined from the first non-Raynaud's phenomenon symptom attributable to SSc, pulmonary function test, frequency of specific capillaroscopic pattern or ESR.

Baseline concentration of APRIL in supernatants of PBMC from patients who subsequently experienced progression of the disease was significantly greater (1326 $\pm 105 \mathrm{pg} / \mathrm{ml} / 10^{5}$ cells) in comparison with SSc patients and stable disease ( $991 \pm 208 \mathrm{pg} / \mathrm{ml} / 10^{5}$ cells) and healthy subjects $(p<0.05)$.

To further investigate the role of APRIL in the progression of SSc, associations between disease outcome and release of APRIL by PBMC and clinical features of the disease were evaluated by means of regression analysis. All parameters which showed significant associations with disease outcome in previous analysis were included.

In regression analysis including duration of Raynaud's phenomenon, modified Rodnan skin score and concentration

\section{Związek pomiędzy uwalnianiem APRIL przez komórki jednojądrowe krwi obwodowej a progresją choroby $u$ chorych na twardzinę układową}

W czasie obserwacji 7 z 22 chorych (32\%) doświadczyło istotnego pogorszenia istniejących lub rozwoju nowych powikłań narządowych i/lub zmarło z powodu powikłań narządowych TU. U pozostałych 15 chorych przebieg kliniczny TU pozostał stabilny w czasie 3-letniego okresu obserwacji. Dokładne porównanie chorych na TU z progresją choroby i bez progresji przedstawiono w tabeli I. Średni czas trwania objawu Raynauda ( \pm SD) był znamiennie krótszy u osób z progresją choroby $(3,9 \pm 3,7$ roku) w porównaniu z chorymi ze stabilnym przebiegiem choroby $(8,1 \pm 5,6$ roku, $p<0,05)$. Zmiany skórne były istotnie większe u chorych, którzy doświadczyli progresji choroby (średnie \pm SD mRSS: $21,9 \pm 12,0)$ w porównaniu ze zmianami w grupie chorych ze stabilnym przebiegiem TU $(8,6 \pm 7,3, p<0,05)$. Uogólniona postać choroby (dSSc) oraz obecność przeciwciał anty-topo I występowały częściej w grupie chorych z progresją choroby w porównaniu z osobami ze stabilnym przebiegiem choroby, jednakże różnice nie były znamienne statystycznie $(p=0,05$ oraz $p=0,07)$ (tab. I).

Przeciwciała ACA były obecne u 40\% pacjentów ze stabilnym przebiegiem choroby i u żadnego z chorych z kliniczną progresją schorzenia. Nie stwierdzano różnic sta- 
Table II. Results of multivariate regression analysis regarding associations between SSc outcome and clinical and laboratory features of the disease

Tabela II. Wyniki regresji wieloczynnikowej dotyczącej związków pomiędzy przebiegiem klinicznym TU a klinicznymi i laboratoryjnymi parametrami choroby

\begin{tabular}{|lcc|}
\hline Clinical or laboratory feature/Parametr kliniczny lub laboratoryjny & Multivariate analysis/Regresja wieloczynnikowa \\
\cline { 2 - 3 } & $\boldsymbol{\beta}$ coefficient & $p$ \\
\hline duration of Raynaud's phenomenon / czas trwania objawu Raynauda & 0.61 & 0.001 \\
\hline mRSS & 0.23 & 0.33 \\
\hline concentration of APRIL / stężenie APRIL & -0.94 & 0.0009 \\
\hline
\end{tabular}

mRSS - modified Rodnan skin score / zmodyfikowany wskaźnik zmian skórnych wg Rodnana

The differences were considered significant at $p<0.05 /$ Wartości $p<0,05$ uznawano za istotne statystycznie

of APRIL in supernatants of PBMC, APRIL levels $(B=-0.94$, $p=0.0009)$ and duration of Raynaud's phenomenon $(B=0.61$, $p=0.001)$, but not $\operatorname{mRSS}(B=0.23, p=0.33)$, were significantly associated with disease outcome (Table II).

\section{Discussion}

Our major finding is that increased release of APRIL by PBMC is associated with worse clinical outcome in patients with SSc. We found that SSc-PBMC produced significantly more APRIL when compared with PBMC from healthy subjects. In SSc patients increased production of APRIL was associated with the presence of anti-topo I antibodies and more severe skin, lung and vascular disease, which is in agreement with our previous report [14]. The presence of anti-topo I antibodies as well as the severity of skin and lung disease have been shown to be associated with worse clinical outcome in different SSc cohorts $[21,22]$. However, in our study release of APRIL was independently associated with disease outcome, as shown by the results of regression analysis. This finding appears of particular interest for several reasons. Firstly, our findings indicate that APRIL might be a new biomarker in SSc which might be helpful is assessing disease prognosis in patients with scleroderma. Indeed, development of new biomarkers allowing early assessment of prognosis is very important in SSc because of significant heterogeneity of the disease and lack of therapies reversing disease-related injury. Whether assessment of APRIL would be helpful in predicting specific SSc-related organ involvement requires further studies.

So far only two other studies have evaluated APRIL concentration in sera of SSc patients [12, 13]. Both reported that serum APRIL concentration was elevated in SSC patients compared with healthy controls; however, the clinical associations of increased APRIL levels were different in these two studies. In the study by Matsushita et al., SSc high serum APRIL levels were associated with greater fre- tystycznych pomiędzy grupą chorych z progresją a grupą ze stabilnym przebiegiem choroby odnośnie do wieku chorych, czasu trwania choroby liczonego od momentu wystąpienia pierwszego objawu TU innego niż objaw Raynauda, oceny czynnościowej płuc, zmian kapilaroskopowych ani OB.

Stężenie APRIL w hodowlach KJKO chorych z progresją choroby było znamiennie wyższe $(1326 \pm 105$ pg/ml/10 komórek) w porównaniu z grupą chorych ze stabilnym przebiegiem TU (991 \pm 208 pg/ml/105 komórek), a także w stosunku do grupy osób zdrowych $(p<0,05)$.

W celu lepszej oceny roli APRIL w progresji TU zbadano związek pomiędzy progresją choroby a uwalnianiem APRIL przez KJKO i cechami klinicznymi choroby na podstawie analizy regresji wieloczynnikowej. W analizie tej uwzględniono wszystkie parametry, które we wcześniejszych analizach wykazywały znamienny związek z progresją choroby.

W analizie regresji obejmującej czas trwania objawu Raynauda, zmodyfikowany test skórny Rodnana i stężenie APRIL w hodowlach KJKO, tylko poziom APRIL $(B=-0,94$, $p=0,0009)$ oraz czas trwania objawu Raynauda $(B=0,61$, $p=0,001)$ wykazywały istotny związek z przebiegiem choroby. Takiej zależności nie stwierdzono w odniesieniu do $\operatorname{mRSS}(B=0,23, p=0,33)$ (tab. $\|)$.

\section{Dyskusja}

Najważniejszym wynikiem prowadzonych badań było wykazanie związku pomiędzy zwiększonym wydzielaniem APRIL przez KJKO a gorszym przebiegiem klinicznym u chorych na TU. Stwierdzono, że KJKO chorych na TU produkują znamiennie więcej APRIL w porównaniu z KJKO osób zdrowych. U chorych na TU zwiększone wytwarzanie APRIL było związane z obecnością przeciwciał anty-topo I i bardziej zaawansowanymi zmianami ze strony skóry, płuc i naczyń krwionośnych, co jest zgodne z wcześniejszym doniesieniem autorów [14]. W różnych populacjach chorych na TU wykazano, że obecność przeciwciał anty-topo I, 
quency of SLD while in the study by Bassyouni et al. high APRIL concentration was associated with the presence of myositis [12-14]. Our findings support the study by Matsushita et al. demonstrating a potential source of elevated production of APRIL in SSc patients. Moreover, we were able to demonstrate significant associations between increased production of APRIL and greater skin involvement, greater vascular damage and the presence of anti-topo I in $\mathrm{SSc}$, indicating that evaluation of ex vivo production of APRIL by PBMC may be a more sensitive method which provides evidence for an association between APRIL and organ damage in SSc patients.

Secondly, the results of our study indicate that APRIL might be involved in the disease process leading to progression of the disease and therefore might represent a new therapeutic target for treating SSc. Indeed, increased production of APRIL might contribute to maintenance of the autoimmune phenomenon in SSc. This aspect is also very important since therapeutic options in SSC are very limited. Of note, the results of recently published small open clinical studies indicate that therapies targeting B cells might improve skin and lung function in SSc [23, 24]. Moreover, the results of these studies, as well as evidence from animal models of skin fibrosis, indicate that therapies targeting $B$ cells decrease fibrosis, which is considered the most important element of the disease process in SSc [24, 25]. Whether targeting APRIL will prove superior to other B-cell targeting therapies remains to be established. However, therapies aimed at blocking APRIL pathways are already available and have been investigated in clinical trials in another autoimmune disease [26]. Atacicept, a recombinant fusion protein comprising the extracellular domain of the TACI receptor, which binds APRIL, has recently been shown to reduce immunoglobulin levels and B cell numbers in patients with systemic lupus erythematosus [27].

In conclusion, we have shown that PBMC from SSC patients produce significantly more APRIL than do PBMC from healthy subjects, and that higher production of APRIL by PBMC is associated with more severe disease and worse clinical outcome in patients with SSc. Further studies are required to clarify whether targeting APRIL might represent a new therapeutic possibility for treatment of SSc patients.

Study was supported by research grant from the Medical University of Bialystok (grant no. 113-60783). jak również większe nasilenie choroby skóry i płuc jest związane z gorszym przebiegiem klinicznym [21, 22]. Jednak w niniejszym badaniu uwalnianie APRIL było niezależnym predyktorem przebiegu choroby, co przedstawiają wyniki analizy regresji. Spostrzeżenie to wydaje się interesujące z różnych powodów. Przeprowadzone badania wskazują, że APRIL może być nowym biomarkerem TU przydatnym w prognozowaniu przebiegu choroby. Identyfikacja nowych biomarkerów pozwalających na wczesną ocenę prognozowania przebiegu choroby jest bardzo istotna w TU z uwagi na znaczne zróżnicowanie choroby zasadniczej i brak ściśle określonego wzorca terapii powstrzymującej proces chorobowy. Konieczne są dalsze badania mające na celu stwierdzenie, czy ocena APRIL może być pomocna w przewidywaniu specyficznego zajęcia procesem chorobowym poszczególnych narządów.

Dotychczas tylko dwa inne badania oceniały stężenie APRIL w surowicy pacjentów z TU $[12,13]$. Obydwa wykazały, że stężenie APRIL w surowicy było wyższe u chorych na TU w porównaniu ze stężeniem w grupie osób zdrowych. Jednakże ocena związku zwiększonego stężenia APRIL z obrazem klinicznym TU była w obu wspomnianych badaniach odmienna. W badaniach Matsushita i wsp. wysokie wartości APRIL były związane z częstym występowaniem ŚChP, natomiast Bassyouni i wsp. stwierdzili związek pomiędzy dużym steżeniem APRIL a zapaleniem mięśni [12-14]. Badania autorów niniejszej pracy potwierdzają wyniki badań Matsushita i wsp. oraz Bassyouni i wsp., wykazując potencjalne źródło wzmożonej syntezy APRIL u chorych z TU. Ponadto autorzy niniejszej pracy wykazali istotną zależność pomiędzy zwiększonym wydzielaniem APRIL a większym zajęciem skóry, większym zniszczeniem naczyń krwionośnych i specyficznym profilem immunologicznym chorych na TU, co wskazuje, że ocena wytwarzania APRIL ex vivo może się stać bardziej czułą metodą ustalającą związek pomiędzy APRIL i stopniem zajęcia narządów u chorych na TU.

Ponadto przedstawione $\mathrm{w}$ niniejszej pracy wyniki wskazują, że APRIL może brać udział w patogenezie TU, prowadząc do jej progresji, i dlatego może się stać nowym celem terapeutycznym w leczeniu chorych na TU. Rzeczywiście zwiększone wytwarzanie APRIL może się przyczyniać do utrzymania zjawisk autoagresji w TU. Takie spostrzeżenie może mieć duże znaczenie, biorąc pod uwagę znikome opcje terapeutyczne w TU. Wyniki ostatnio opublikowanych otwartych badań klinicznych wskazują, że terapia skierowana przeciwko komórkom B może poprawić funkcję skóry i płuc u chorych na TU [23, 24]. Ponadto wyniki tych badań, jak również wyniki badań na zwierzęcych modelach włóknienia skóry wskazują, że terapia ukierunkowana na komórki B może zmniejszać włóknienie uważane za najważniejszy element w procesie choroby [24, 25]. Przyszłe badania wykażą, czy wpływ farmakologiczny na 
APRIL okaże się lepszą opcją leczenia niż dotychczasowe terapie skierowane przeciwko komórkom B. Należy wspomnieć, że obecnie prowadzone są badania kliniczne blokowania szlaku APRIL w innych chorobach autoimmunologicznych [26]. Wykazano m.in., że atacicept (rekombinowane białko zawierające pozakomórkową domenę receptora $\mathrm{TACl}$, który wiąże się z APRIL) zmniejsza stężenie immunoglobulin i liczbę komórek B u chorych na toczeń rumieniowaty układowy [27].

Podsumowując - w niniejszej pracy wykazano, że KJKO chorych na TU wytwarzają istotnie więcej APRIL niż KJIKO osób zdrowych i że zwiększona produkcja APRIL w hodowlach KJKO jest związana z większym nasileniem choroby oraz gorszym przebiegiem klinicznym u chorych na TU. Potrzebne są dalsze badania mające na celu wyjaśnienie, czy blokowanie APRIL może się stać nową opcją farmakoterapii chorych na TU.

Badania były finansowane w ramach projektu statutowego Uniwersytetu Medycznego w Biatymstoku (projekt nr 113-60783).

\section{References}

\section{Piśmiennictwo}

1. Kowal-Bielecka O, Bielecki M. Twardzina układowa. W: Reumatologia Puszczewicz M (red.). Wielka interna Antczak A, Myśliwiec M, Pruszczyk P (red.). Medical Tribune Polska, Warszawa 2010; 127-141.

2. Charles C, Clements P, Furst DE. Systemic sclerosis: hypothesisdriven treatment strategies. Lancet 2006; 367: 1683-1691.

3. Gu YS, Kong J, Cheema GS, et al. The immunobiology of systemic sclerosis. Semin Arthritis Rheum 2008; 38: 132-160.

4. Lafyatis $R$, York $M$. Innate immunity and inflammation in systemic sclerosis. Curr Opin Rheumatol 2009; 21: 617-622.

5. Chizzolini C. T cells, B cells, and polarized immune response in the pathogenesis of fibrosis and systemic sclerosis. Curr Opin Rheumatol 2008; 20: 707-712.

6. Daoussis D, Liossis SN, Yiannopoulos G, Andonopoulos AP. B-cell depletion therapy in systemic sclerosis: experimental rationale and update on clinical evidence. Int J Rheumatol 2011; 2011: 214013.

7. Cepeda EJ, Reveille JD. Autoantibodies in systemic sclerosis and fibrosing syndromes: clinical indications and relevance. Curr Opin Rheumatol 2004; 16: 723-732.

8. Bossen C, Schneider P. BAFF, APRIL and their receptors: structure, function and signaling. Semin Immunol 2006; 18: 263-275.

9. Ferrer G, Hodgson K, Montserrat E, Moreno C. B cell activator factor and a proliferation-inducing ligand at the cross-road of chronic lymphocytic leukemia and autoimmunity. Leuk Lymphoma 2009; 50: 1075-1082

10. Koyama T, Tsukamoto H, Miyagi Y, et al. Raised serum APRIL levels in patients with systemic lupus erythematosus. Ann Rheum Dis 2005; 64: 1065-1067.
11. Jonsson MV, Szodoray P, Jellestad S, et al. Association between circulating levels of the novel TNF family members APRIL and BAFF and lymphoid organization in primary Sjögren's syndrome. J Clin Immunol 2005; 25: 189-201.

12. Matsushita T, Fujimoto M, Hasegawa M, et al. Elevated serum APRIL levels in patients with systemic sclerosis: distinct profiles of systemic sclerosis categorized by APRIL and BAFF. J Rheumatol 2007; 34: 2056-2062.

13. Bassyouni IH, Azab NA, El-Dakrony, et al. Elevated serum levels of a proliferation-inducing ligand in patients with systemic sclerosis: possible association with myositis? Joint Bone Spine 2011; 78: 56-61.

14. Bielecki M. Kowal K, Lapinska A, et al. Increased production of a proliferation-inducing ligand (APRIL) by peripheral blood mononuclear cells is associated with antitopoisomerase I antibody and more severe disease in systemic sclerosis. J Rheumatol 2010; 37: 2286-2289.

15. Subcommittee for scleroderma criteria of the American Rheumatism Association Diagnostic and Therapeutic Criteria Committee. Preliminary criteria for the classification of systemic sclerosis (scleroderma). Arthritis Rheum 1980; 23: 581-590.

16. LeRoy EC, Medsger TA Jr. Criteria for the classification of early systemic sclerosis. J Rheumatol 2001; 28: 1573-1576.

17. LeRoy EC, Black C, Fleischmajer R, et al. Scleroderma (systemic sclerosis): classification, subsets and pathogenesis. J Rheumatol 1988; 15: 202-205.

18. Postlethwaite AE, Wong WK, Clements P, et al. A multicenter, randomized, double-blind, placebo-controlled trial of oral type I collagen treatment in patients with diffuse cutaneous systemic sclerosis: oral type I collagen does not improve skin in all patients, 
but may improve skin in late-phase disease. Arthritis Rheum 2008; 58: 1810-1822.

19. Carpentier PH, Maricq HR. Microvasculature in systemic sclerosis. Rheum Dis Clin North Am 1990; 16: 75-91.

20. Gilson M, Zerkak D, Wipff J, et al. Prognostic factors for lung function in systemic sclerosis: prospective study of 105 cases. Eur Respir J 2010; 35: 112-117.

21. Clements PJ, Hurwitz EL, Wong WK, et al. Skin thickness score as a predictor and correlate of outcome in systemic sclerosis: highdose versus low-dose penicillamine trial. Arthritis Rheum 2000; 43: 2445-2454.

22. Goh NS, Desai SR, Veeraraghavan S, et al. Interstitial lung disease in systemic sclerosis: a simple staging system. Am J Respir Crit Care Med 2008; 177: 1248-1254.

23. Daoussis D, Liossis SN, Tsamandas AC, et al. Experience with rituximab in scleroderma: results from a 1-year, proof-ofprinciple study. Rheumatology (Oxford) 2010; 49: 271-280.

24. Daoussis D, Tsamandas AC, Liossis SN, et al. B-cell depletion therapy in patients with diffuse systemic sclerosis associates with a significant decrease in PDGFR expression and activation in spindle-like cells in the skin. Arthritis Res Ther 2012; 14: R145.

25. Komura K, Yanaba K, Horikawa M, et al. CD19 regulates the development of bleomycin-induced pulmonary fibrosis in a mouse model. Arthritis Rheum 2008; 58: 3574-3584.

26. Dall'Era M, Chakravarty E, Wallace D, et al. Reduced B lymphocyte and immunoglobulin levels after atacicept treatment in patients with systemic lupus erythematosus: results of a multicenter, phase Ib, double-blind, placebo-controlled, dose-escalating trial. Arthritis Rheum 2007; 56: 4142-4150.

27. Bracewell C, Isaacs JD, Emery P, Ng WF. Atacicept, a novel B celltargeting biological therapy for the treatment of rheumatoid arthritis. Expert Opin Biol Ther 2009; 9: 909-919. 